\title{
Transmission of caprine arthritis encephalitis virus between sheep
}

\author{
Carla Caroline Valença de Lima $^{1^{*}}$ - Maria Consuêlo Caribé Ayres ${ }^{2}$ \\ Raymundo Rizaldo Pinheiro ${ }^{3}$ Joselito Nunes Costa $^{4} \odot$ \\ Thiago Sampaio de Souza $^{5}$ (2) Alice Andrioli Pinheiro ${ }^{3}$ \\ Dalva Alana Aragão Azevedo ${ }^{6}$. Vanderlan Warlington Souza dos Santos $^{7} \mathrm{C}$
}

${ }^{1}$ Centro de Ciência da Saúde, Universidade Federal do Recôncavo da Bahia (UFRB), Avenida Carlos Amaral, s/n, Cajueiro, 40170-110, Santo Antônio de Jesus, BA, Brasil. E-mail: carlacvlima@gmail.com. * Corresponding author.

${ }^{2}$ Departamento de Patologia e Clínicas, Escola de Medicina Veterinária, Universidade Federal da Bahia (UFBA), Salvador, BA, Brasil.

${ }^{3}$ Centro Nacional de Pesquisa de Caprinos, Empresa Brasileira de Pesquisa Agropecuária - Embrapa Caprinos e Ovinos, Estrada Sobral Groaíras, Sobral, CE, Brasil.

${ }^{4}$ Centro de Ciências Agrárias Ambientais e Biológicas, Universidade Federal do Recôncavo da Bahia (UFRB), Cruz das Almas, BA, Brasil.

${ }^{5}$ Hospital Universitário de Medicina Veterinária, Universidade Federal do Recôncavo da Bahia (UFRB), Cruz das Almas, BA, Brasil.

${ }^{6}$ Programa de Pós-graduação em Ciências Veterinárias, Universidade Estadual do Ceará (UECE), Fortaleza, CE, Brasil.

${ }^{7}$ Ciência Animal, Universidade Federal Rural do Semi-Árido (UFERSA), Mossoró, RN, Brasil.

ABSTRACT: This study was conducted to evaluate caprine arthritis encephalitis virus (CAEV) transmission among sheep using 15 lambs that were distributed in 2 experimental groups. The exposed group consisted of 10 lambs that remained with their mothers, who were experimentally infected with CAEV. The non-exposed group was characterized as the control group and was comprised of 5 lambs that remained with their CAEV-negative mothers. Blood samples were collected monthly from birth until 1 year of life. To evaluate the transmission, an agar gel immunodiffusion test (AGID), enzyme immunoassay (ELISA), immunoblotting (IB), and nested polymerase chain reaction (nPCR) techniques were used. The non-exposed group was negative in all of the tests throughout the whole experiment. In the exposed group, 2 individuals had positive $n P C R$ results. Positive $n P C R$ samples were sequenced for comparison with the original goat strains and were shown to be similar to the CAEV-Cork strain. Seroconversion was not detected, and clinical manifestations were not observed. Thus, after 1 year of observation, it was verified that CAEV transmission among sheep is possible; however, with discreet frequency. This was an initial study, and other experiments are needed to analyze the adaptive capacity of the CAEV to remain in an infected sheep flock and cause the disease.

Key words: lentiviruses, CAEV, MVV, intra-species transmission, SRLV.

Transmissão do vírus da artrite encefalite caprina entre ovinos

RESUMO: O estudo foi conduzido para avaliar a transmissão do vírus da artrite encefalite caprina (CAEV) entre ovinos, utilizando 15 cordeiros, distribuidos em dois grupos experimentais. O grupo exposto foi constituido por 10 cordeiros, mantidos com suas mães, que foram infectadas, experimentalmente, com CAEV. O grupo não exposto caracterizou-se como grupo controle e foi formado por cinco cordeiros, mantidos com suas matrizes, negativas para CAEV. Foram colhidas amostras de sangue mensalmente, do periodo que compreende o nascimento até um ano de vida. Para avaliar a transmissão, foram utilizadas as técnicas de imunodifusão em gel de agarose (IDGA), ensaio imunoenzimático (ELISA), immunoblotting (IB) e reação em cadeia da polimerase do tipo nested (nPCR). O grupo não exposto se manteve negativo aos testes durante todo o experimento. Já no grupo exposto, dois individuos apresentaram resultados positivos na nPCR. As amostras positivas na nPCR foram sequenciadas para serem comparadas com as cepas originais de caprinos, comprovando se tratar de lentivírus semelhante à cepa CAEV-Cork. A soroconversão não foi detectada e a manifestação clínica não foi observada. Sendo assim, após um ano de observação, verificou-se que a transmissão do CAEV entre ovinos é possível, entretanto, com discreta frequência. Este foi um estudo inicial, e outros experimentos são necessários para analisar a capacidade adaptativa do CAEV de permanecer em rebanho ovino infectado e, com isso, causar doença.

Palavras-chave: Lentiviroses, CAEV, LVPR, MVV, transmissão intra-espécie.

\section{INTRODUCTION}

Lentiviruses are a group of marked importance in human and veterinary medicine, because they cause chronic and incurable degenerative syndromes. This group includes the small ruminant lentivirus (SRLV), etiologic agents of caprine arthritis encephalitis (CAE) in goats, and maedi-visna (MV) in sheep (LEROUX \& MORNEX, 2008; LEROUX et al., 2010; SOUZA et al., 2012).

Both goat and sheep lentiviruses have multiple clinical manifestations, including articular, neurological, respiratory, and mammary ones, in addition to progressive weight loss (BLACKLAWS, 2012; HASEGAWA et al., 2016). Ingestion of contaminated milk and colostrum and inhalation 
of respiratory secretions have been suggested as the main routes of transmission. This transmission can be both vertical, such as from the mother to the offspring, and horizontal from direct contact between animals (ÁLVAREZ et al., 2005; ÁLVAREZ et al., 2006; VILLORIA et al., 2013; LIMA et al., 2017).

The first reports of CAE demonstrated the similarity of the disease in goats and sheep (ADAMS \& CRAWFORD, 1980; DAWSON, 1987). In addition, previous studies have verified the possibility for the cross-infection of lambs and kids by caprine arthritis encephalitis virus (CAEV) and maedi-visna virus (MVV), respectively (OLIVER et al., 1982; BANKS et al., 1983; OLIVER et al., 1984). Later, genomic studies of SRLV indicated a heterogeneous group of virological agents, encompassing goats and sheep, with a variation in pathogenicity that led to its characterization as a viral quasispecies (PASICK, 1998; SHAH et al., 2004; LEROUX et al., 2010; RACHID et al., 2013).

In the classification of SRLV based on genomic sequences, group A contains isolated strains that are related to $\mathrm{MVV}$, and group B has isolated strains that are related to CAEV. Strains with high divergences from groups $\mathrm{A}$ and $\mathrm{B}$ were classified as C, D, and E. Group A has at least 15 subtypes, and group B has at least 3 subtypes. Strains homologous to the prototype of the goat virus (the CAEV-Cork strain) were classified as subtype B1, and strains homologous to the prototype of the virus in sheep (the MVV-K1514 strain) were classified as subtype A1 (SHAH et al., 2004; SOUZA et al., 2012).

A study showing the transmission of CAEV from goat to sheep was performed (SOUZA et al., 2015); however, the capacity for transmission of this infection between sheep was not determined. Therefore, the research in the present study examined the transmission of CAEV among sheep.

\section{MATERIALS AND METHODS}

This research was conducted with 3 isolated experimental spaces with distinct populations; the first consisted of dairy goats infected with a subtype B1 CAEV strain, as described in the study by FEITOSA et al. (2010), from which milk and colostrum were obtained to give to the second population. The second flock was comprised of female sheep experimentally infected with CAEV during the neonatal stage, by ingesting colostrum and milk from dairy goats (SOUZA et al., 2015; LIMA et al., 2017). The third flock consisted of 10 lambs, the offspring of the second flock, from which one of the experimental units (the exposed group) in this study was obtained.
Two experimental groups were established: the exposed group, composed of 10 lambs that remained with their CAEV-infected mothers, and the non-exposed group, which was also called the control group, comprised of 5 lambs that remained with their mothers, who were negative for CAEV. The 2 groups were kept isolated in 2 separate locations, in an intensive breeding system, specific for experiments with SRLV. Ewes were kept with their lambs until 120 days of birth, when weaning was executed.

Infection status of the mothers was evaluated by an agar gel immunodiffusion test (AGID), enzyme immunoassay (ELISA), immunoblotting (IB), and nested polymerase chain reaction (nPCR). The 10 mothers of the exposed group were positive based on the nPCR results for the blood; although, without clinical signs, and 2 of them had seroconversion (SOUZA et al., 2015). Milk samples from 2 of the 10 ewes were positive in nPCR (LIMA et al., 2017). The 5 mothers of the nonexposed group had negative results from the nPCR and serological tests.

In order to verify the transmission of CAEV among sheep, these 15 lambs were evaluated from birth until one year of life. The times of collection were: the first through the fifth day of life, and then monthly until 12 months of life, totaling 13 samples for each animal. Two samples of blood were obtained by venipuncture of the jugular in a vacuum system: the first sample consisted of $5 \mathrm{~mL}$ in tubes without anticoagulant in order to obtain the blood serum, which was used for the serological techniques AGID, ELISA, and IB; and the second sample contained $10 \mathrm{~mL}$ of blood with anticoagulant (EDTA) to obtain the peripheral blood leukocytes (PBL) for DNA extraction.

The PBL were obtained by centrifugation of the total blood and treated with ammonium chloride, according to the protocol suggested by FEITOSA et al. (2011). From this material, the extraction of DNA was performed using lithium chloride (GRIMBERG et al., 1989). PCR was performed following the methodology described by BARLOUGH et al. (1994) and modified by ANDRIOLI et al. (2006).

Two rounds of PCR amplification (nested PCR) were used to detect the $187 \mathrm{bp}$ proviral DNA fragment, which corresponded to the gag leader sequence of the CAEV genome. Two pairs of primers were selected, based on the published sequence of the CAEVCork strain (SALTARELLI et al., 1990). The primers $\mathrm{P}_{1}$ (5'-CAAGCAGCAGGAGGGAGAAGCTG-3') and $\mathrm{P}_{2} \quad\left(5^{\prime}\right.$-TCCTACCCCCATAATTTGATCCAC$\left.3^{\prime}\right)$ were used for the first amplification 
(BARLOUGH et al., 1994), and the primers $\mathrm{P}_{3}$ (5'-GTTCCAGCAACTGCAAACAGTAGCAATG-3') andP $_{4}\left(5^{\prime}\right.$-ACCTTTCTGCTTCTTCATTTAATTTCCC3 ') were used for the second amplification (RIMSTAD et al., 1993). A negative control, consisting of autoclaved ultrapure water, and a positive control, obtained from the cell culture of a goat synovial membrane (GSM) infected with the CAEV-Cork strain, were used.

In order to compare the positive DNA fragments from nPCR, the samples were sequenced in platform with an Applied Biosystems ${ }^{\circledR} 3500$ Genetic Analyzer. The sequences were then aligned using Clustal W (THOMPSON et al., 1994) with the BioEdit Sequence Alignment Editor ${ }^{\circledR}$ (HALL, 1999) program and compared with the sequences of the standard CAEV-Cork and MVV-K1514 strains, available in GenBank under accession numbers M33677 and M60610, respectively, in addition to the sequence obtained from the circulating strain in the flock of goats used as the source of infection for the sheep (BR/CNPC-G1), which had been classified as subtype B1 (FEITOSA et al., 2010).

To verify the immune response of the lambs to CAEV, 3 serological tests were used to test their feasibility as a diagnostic tool: AGID, as it is the technique used and regulated in the country; ELISA, in order to increase the detection capability of the immune response, because this technique is more sensitive than the previous one (LIMA et al., 2013); and IB as a confirmatory technique, as it has the best diagnostic performance of the 3 (RODRIGUES et al., 2014).

Antigens were produced from the secondary cultivation of GSM, which had been inoculated with the CAEV-Cork standard strain (PINHEIRO et al., 2006; PINHEIRO et al., 2010). For AGID, an ultrafiltration antigen was used (PINHEIRO et al., 2010). In ELISA, an antigen obtained from a pellet of cells treated with sodium dodecyl sulfate (SDS) was used, according to the method of TORRES et al. (2009). For IB, the antigen produced from ultracentrifugation with a sucrose cushion was used (PINHEIRO et al., 2006). The AGID tests were performed according to method of PINHEIRO et al. (2010). The ELISA was validated following the methodology described by LIMA et al. (2013). The IB tests were performed according to RODRIGUES et al. (2014). For all of the serological tests, a positive control from the animals infected with CAEV and a negative control from a healthy animal were used.

\section{RESULTS AND DISCUSSION}

Two animals from the exposed group had a positive nPCR result: one in the first 5 days of life (lamb 54), and the other at 180 days of age (lamb 52). A positive nPCR result indicated proviral DNA detection (ÁLVAREZ et al., 2006). Therefore, results suggestedthe possibility of CAEV transmission between sheep. All of the tests performed for the control group were negative, showing that there was no other source of infection, aside from the infected ewes in the exposed group.

It was not possible to determine if the transmission route was vertical from feeding with milk and colostrum or horizontal from contact. However, the detection of proviral DNA in the first 5 days of life for lamb 54 suggested vertical transmission, and the detection at 180 days of age for lamb 52 suggests horizontal transmission. SOUZA et al. (2015) demonstrated positive results with nPCR in lambs at 7 days of age, by suckling colostrum and milk from goats infected with CAEV. These authors also detected horizontal transmission of the virus from goats infected with CAEV to healthy sheep within the first 30 days of contact.

Only 1 animal (lamb 73) from the exposed group had positive results from IB, ELISA, and AGID during the first 5 days of life. The mother of this lamb was 1 of the 2 sheep that seroconverted to exhibit positive results in IDGA, ELISA, and IB. Therefore, the positive detection was associated with the transfer of maternal immunoglobulins, as antibodies from passive immunity may be detected by IB until 70 days of age, and by ELISA and AGID until 50 days (SOUZA et al., 2014). Another animal (lamb 56) from the exposed group demonstrated a positive result with ELISA at 300 days. However, this result was attributed to a nonspecific reaction, constituting a false positive, as no positivity was observed with the IB test.

There were no clinical manifestations of small ruminant lentiviruses in the exposed group. It is known; however, that the time required for seroconversion and manifestation of the disease in animals infected with CAEV is variable, and some animals do not seroconvert nor present with a clinical manifestation (LARA et al., 2003; ÁLVAREZ et al., 2005; PAULA et al., 2009; RACHID et al., 2013).

Goats infected with subtype B1 CAEV have chronic arthritis, chronic interstitial pneumonia, and interstitial indurative mastitis (HASEGAWA et al., 2016). In this study, the strain transmitted among the sheep was derived from dairy goats infected with CAEV of subtype B1 (FEITOSA et al., 2010). Therefore, it is possible to explain the discreet detection of positive nPCR results, the lack of clinical signs, and the absence of seroconversion by 
the change in species, for which the Lentivirus strain is adapted (RACHID et al., 2013). The interspecies transmission of CAEV from goats to sheep was confirmed by SOUZA et al. (2015), and the intraspecies transmission of CAEV among sheep was demonstrated in this report. However, it is possible that the infection was transient (HERRMANNHOESING et al., 2007).

Conversely, these results can also be explained by viral intermittence in blood, as identified by other authors during the follow-up of infected animals (ÁLVAREZ et al., 2005; PAULA et al., 2009), which does not mean a lack of infection. The behavior of the virus in the intracellular environment is variable, because it can remain in a state called quiescence, when the proviral DNA, even if integrated with the cellular DNA, has not been activated and is; therefore, not multiplying, or the DNA can be inside the cell but not integrated (CAVALCANTE et al., 2013; BLACKLAWS, 2012; CRUZ et al., 2013).

The lack of viral replication reduces the ability to detect its genetic material in tissues (BARQUERO et al., 2013). In addition, the detection capability of the serological techniques is directly related to the level of viral replication that can generate a humoral immune response (TORRES et al., 2009). This diagnostic limitation may be reduced by combining different methods (BARQUERO et al. 2013); however, viral intermittence must be considered (RAVAZZOLO et al., 2006; RACHID et al., 2013).

The samples with positive nPCR results were purified and sequenced, in order to compare them with the original goat strains (Figure 1). While observing the obtained sequences, it was possible to verify a difference of $2 \%$ in the sequence from lamb 52, compared to the CAEV standard strains CAEVCork and BR/CNPC-G1, indicating a variation. Lamb 54 had 100\% homology with CAEV-Cork and BR/ CNPC-G1. Regarding the similarity with the MVV standard strain MVV-K1514, lamb 52 had $89 \%$ homology, and lamb 54 had 90\% homology.

The modification observed for animal 52 may be a mutation (BARQUERO et al., 2013); however, additional detailed studies are needed to confirm this hypothesis, mainly because lamb 54 did not manifest this. The low similarity with strain MVV-K1514 indicated the differences between the sequences reported in the lambs compared to the ovine lentivirus.

These data demonstrate that the transmission and dissemination of lentiviruses are more complex than the hypothesis of them being species-specific (GERMAIN \& VALAS, 2006; REINA et al., 2006). The occurrence of quasispecies is closely linked to



Ciência Rural, v.48, n.10, 2018. 
avoidance schemes of the immune response, which are mainly related to errors in the transcription of viral RNA by reverse transcriptase (PASICK, 1998; LEROUX \& MORNEX, 2008; BLACKLAWS, 2012). However, this fact does not contradict the possibility that some strains are more adapted to goats and others to sheep, and that the interaction between these species happens in a different way (SHAH et al., 2004; RACHID et al., 2013).

\section{CONCLUSION}

The occurrence of CAEV transmission among sheep is possible; however, with discreet frequency. Further studies are needed to evaluate the ability of the goat virus to persist in sheep.

\section{ACKNOWLEDGEMENTS}

We acknowledge the Fundação de Amparo à Pesquisa do Estado da Bahia (FAPESB) for the promotion of the project, the Conselho Nacional de Desenvolvimento Científico e Tecnológico (CNPq) for research funding, the Coordenação de Aperfeiçoamento de Pessoal de Nível Superior (CAPES) for scholarships, and the Empresa Brasileira de Pesquisa Agropecuária (Embrapa) - Goats and Sheep for supporting the implementation of the experiment.

\section{BIOETHICS AND BIOSSECURITY COMMITTE APPROVAL}

Project approved by the Ethics Committee on Animal Use from Universidade Estadual do Vale do Acaraú, Sobral, Ceará State, Brazil (number 001/2012).

\section{DECLARATION OF CONFLICTING INTERESTS}

The authors declared no potential conflicts of interest with respect to the research, authorship, and/or publication of this article.

\section{AUTHORS' CONTRIBUTIONS}

The authors contributed equally to the manuscript.

\section{REFERENCES}

ADAMS, D.S.; CRAWFORD, T.B. CAE: viral arthritisencephalitis syndrome in goats. International Goat and Sheep Research, v.1, n.2, p.168-172, 1980.

ÁLVAREZ, V. et al. Relative contribution of colostrum from MaediVisna virus (MVV) infected ewes to MVV - seroprevalence in lambs. Research in Veterinary Science, v.78, n.3, p.237-243, 2005. Available from: $<$ https://www.sciencedirect.com/science/article/pii/ S0034528804001857>. Accessed: Jan. 24, 2018. doi: 10.1016/j. rvsc.2004.09.006.

ÁLVAREZ, V. et al. PCR detection of colostrum-associated MaediVisna virus (MVV) infection and relationship with ELISA antibody status in lambs. Research in Veterinary Science, v.80, n.2, p.226-234, 2006. Available from: <https://www.ncbi.nlm.nih. gov/pubmed/16045950>. Accessed: Jan. 25, 2018. doi: 10.1016/j. rvsc. 2005.05.008.

ANDRIOLI, A. et al. Risk factors in caprine lentivirus transmission through semen. Pesquisa Agropecuária Brasileira, v.41, n.8, p.1313-1319, 2006. Available from: <http://www.scielo. br/scielo.php?pid=S0100-204X2006000800015\&script $=$ sci abstract\&tlng=es $>$. Accessed: Jan. 25, 2018. doi: 10.1590/S0100204X2006000800015.

BANKS, K.L. et al. Experimental infection of sheep by caprine arthritis-encephalitis virus and goats by progressive pneumonia virus. American Journal of Veterinary Research, v.44, n.12, p.2307-2311, 1983.

BARLOUGH, J. et al. Double-nested polymerase chain reaction for detection of caprine arthritis-encephalitis virus proviral DNA in blood, milk, and tissues of infected goats. Journal of Virological Methods, v.50, n. 1-3, p.101-113, 1994. Available from: <https:// www.ncbi.nlm.nih.gov/pubmed/7714032>. Accessed: Jan. 25, 2018.

BARQUERO, N. et al. Evolution of specific antibodies and proviral DNA in milk of small ruminants infected by small ruminant lentivirus. Viruses, v.5, n.10, p.2614-2623, 2013. Available from: $<$ https://www.ncbi.nlm.nih.gov/pubmed/24153063>. Accessed: Jan. 25, 2018. doi: 10.3390/v5102614.

BLACKLAWS, B.A. Small ruminant lentiviruses: Immunopathogenesis of visna-maedi and caprine arthritis and encephalitis virus. Comparative Immunology, Microbiology and Infectious Diseases, v.35, n.3, p.259-269, 2012. Available from: <https://www.sciencedirect.com/ science/article/pii/S0147957111001111>. Accessed: Jan. 24, 2018. doi: 10.1016/j.cimid.2011.12.003.

CAVALCANTE, F.R.A. et al. Caprine Arthritis Encephalitis virus is detected in oocytes and uterine fluid by nested PCR and nested RT-PCR. Arquivos do Instituto Biológico, v.80, n.4, p.381-386, 2013. Available from: $<$ http://www.scielo.br/scielo.php?pid=S1808$16572013000400381 \&$ script $=$ sci abstract\&tlng $=\mathrm{pt}>$. Accessed: Jan. 25, 2018. doi: 0.1590/S1808-16572013000400002.

CRUZ, J.C.M. et al. Small ruminant lentiviruses (SRLVs) break the species barrier to acquire new host range. Viruses, v.5, n.7, p.1867-1884, 2013. Available from: <https:/www.ncbi.nlm.nih.gov/ pubmed/23881276>. Accessed: Jan. 25, 2018. doi: 10.3390/v5071867.

DAWSON, M. Caprine arthritis-encephalitis. In Practice, v.9, p.8$11,1987$.

FEITOSA, A.L.V.L. et al. Firt isolation of small ruminant lentivirus from a naturally infected goat in a flock in the state of Rio Grande do Norte, Brazil. Arquivos do Instituto Biológico, v.78, n. 4, p.501-505, 2011. Available from: <http://www.biologico.sp.gov. br/uploads/docs/arq/v78_4/feitosa.pdf >. Accessed: Jan. 25, 2018.

FEITOSA, A.L.V.L. et al. Phylogenetic analysis of small ruminant lentiviruses from Northern Brazil. Small Ruminant Research, v.94, n.1-3, p.205-209, 2010. Available from: <https://www. sciencedirect.com/science/article/pii/S092144881000221X>. Accessed: Jan. 25, 2018. doi: 10.1016/j.smallrumres.2010.07.020.

GERMAIN, K.; VALAS, S. Distribution and heterogeneity of small ruminant lentivirus envelope subtypes in naturally infected sheep. Virus Research, v.120, n.1-2, p.156-162, 2006. Available from: <https:// 
www.sciencedirect.com/science/article/pii/S016817020600075X >. Accessed: Jan. 25, 2018. doi: 10.1016/j.virusres.2006.03.002.

GRIMBERG, J. et al. A simple and efficient non-organic procedure for the isolation of genomic DNA from blood. Nucleic Acids Research, v.17, n. 20, p.83-90, 1989. Available from: $<$ https://www.ncbi.nlm.nih. gov/pmc/articles/PMC334995/>. Accessed: Jan. 25, 2018.

HALL, T.A. Bioedit: a user-friendly biological sequence alignment editor and analysis program for Windows 95/98/NT. Nucleic Acids Symposium Series, v.41, p.95-98, 1999. Available from: <https:// www.scienceopen.com/document?vid=690e7265-f2ce-4d9c-82a2399cca46fbef $>$. Accessed: Jan. 25, 2018. doi: 10.12691/ajmr-3-2-1.

HASEGAWA, M.Y. et al. Small ruminant lentivirus variants and related clinical features in goats from southeastern Brazil. Small Ruminant Research, v. 140, p.32-36, 2016. Available from: $<$ https:// www.sciencedirect.com/science/article/pii/S0921448816301407>. Accessed: Jan. 24, 2018. doi: 1016/j.smallrumres.2016.05.019.

HERRMANN-HOESING, L.M. et al. Evidence of proviral clearance following postpartum transmission of an ovine lentivirus. Virology, v.362, n.1, p.226-234, 2007. Available from: <https:// www.ncbi.nlm.nih.gov/pubmed/17267002>. Accessed: Jan. 25, 2018. doi: 10.1016/j.virol.2006.12.021.

LARA, M.C.C.S.H. et al. Caprine arthritis-encephalitis vírus experimental infection in kid goats. Arquivos do Instituto Biológico, v.70, n.1, p.51-54, 2003. Available from: $<$ http://www. biologico.agricultura.sp.gov.br/uploads/docs/arq/V70_1/lara.pdf $>$. Accessed: Jan. 25, 2018.

LEROUX, C.; MORNEX, J.F. Retroviral infections in sheep and the associated diseases. Small Ruminant Research, v.76, n.1-2, p.6876, 2008. Available from: $<$ https://www.sciencedirect.com/science/ article/pii/S0921448807002799>. Accessed: Jan. 24, 2018. doi: 10.1016/j.smallrumres.2007.12.010.

LEROUX, C. et al. SRLVs: A genetic continuum of lentiviral species in sheep and goats with cumulative evidence of cross species transmission. Current HIV Research, v.8, n.1, p.94-100, 2010. Available from: <https://www.ncbi.nlm.nih.gov/pubmed/20210785>. Accessed: Jan. 25, 2018. doi: 10.2174/157016210790416415.

LIMA, C.C.V. et al. Immunodiagnostic for artrithis encephalitis caprine in flocks of semi-arid region in Bahia state, Brazil. Brazilian Journal of Veterinary Medicine, v.35, n.4, p.358-364, 2013. Available from: $<$ http://www.rbmv.com.br/?link=verart\&tip $\mathrm{o}=\mathrm{ID \&}$ campo1=794>. Accessed: Jan. 25, 2018.

LIMA, C.C.V. et al. Caprine lentivirus in sheep milk and semen. Arquivo Brasileiro de Medicina Veterinária e Zootecnia, v.69, n.2, p.391-397, 2017. Available from: <http:/www.scielo.br/ scielo.php?script=sci_arttext\&pid=S0102-09352017000200391>. Accessed: Jan. 25, 2018. doi: .1590/1678-4162-8974.

OLIVER, R.E. et al. Experimental infection of sheep and goats with caprine arthritis-encephalitis virus. New Zealand Veterinary Journal, v.30, p.158-159, 1982.

OLIVER, R. et al. Transmission of caprine arthritis encephalitis virus to sheep. New Zealand Veterinary Journal, v. 32, p.199$200,1984$.

PASICK, J. et al. Maedi-visna virus and caprine arthritisencephalitis virus: distinct species or quasispecies and its implications for laboratory diagnosis. Canadian Journal of Veterinary Research, v.62, n.4, p.241-244, 1998. Available from: $<$ https://www.ncbi.nlm.nih.gov/pmc/articles/PMC1189488/>. Accessed: Jan. 25, 2018.

PAULA, N.R.O. et al. Profile of the caprine arthritis-encephalitis virus (CAEV) in blood, semen from bucks naturally and experimentally infected in the semi-arid region of Brazil. Small Ruminant Research, v.85, n.1, p.27-33, 2009. Available from: <https:// www.sciencedirect.com/science/article/pii/S0921448809001163>. Accessed: Jan. 25, 2018. doi: 10.1016/j.smallrumres.2009.06.018.

PINHEIRO, R.R. et al. The development of dot-blot for the detection of antibodies to Caprine Arthritis Encephalitis virus in goat. Revista Portuguesa de Ciências Veterinárias, v.101, n. 557-558, p.51-56, 2006. Available from: $<$ https://www.alice.cnptia.embrapa. br/bitstream/doc/909420/1/APIDesenvolvimentodedotblot.pdf $>$. Accessed: Jan. 25, 2018.

PINHEIRO, R.R. et al. Antigen evaluation for the diagnosis of lentivirus in goat herds under not under a control program. Arquivos do Instituto Biológico, v.77, n.1, p.133-137, 2010. Available from: $<$ http://www.biologico.sp.gov.br/uploads/docs/arq/v77_1/pinheiro. pdf $>$. Accessed: Jan. 25, 2018.

RACHID, A. et al. Diverse host-virus interactions following caprine arthritis-encephalitis virus infection in sheep and goats. Journal of General Virology, v.94, p.634-642, 2013. Available from: <https:// www.ncbi.nlm.nih.gov/pubmed/23197577>. Accessed: Jan. 25, 2018. doi: 10.1099/vir.0.044768-0.

RAVAZZOLO, A.P. et al. Viral load, organ distribution, histopathological lesions and cytokine mRNA expression in goats infected with a molecular clone of the caprine arthritis encephalitis virus. Virology, v.350, n.1, p.116-127, 2006. Available from: $<$ https:// www.ncbi.nlm.nih.gov/pubmed/16537085>. Accessed: Jan. 25, 2018. doi: 10.1016/j.virol.2006.02.014.

REINA, R. et al. Molecular characterization and phylogenetic study of Maedi Visna and Caprine Arthritis Encephalitis viral sequences in sheep and goats from Spain. Virus Research, v.121, n.2, p.189-198, 2006. Available from: <https:/www.ncbi.nlm.nih. gov/pubmed/16870297>. Accessed: Jan. 25, 2018. doi: 10.1016/j. virusres.2006.05.011.

RIMSTAD, E. et al. Delayed seroconversion following naturally acquired caprine arthritis-encephalitis virus infection in goats. American Journal of Veterinary Research, v.54, n.11, p.18581862, 1993. Available from: <https://www.ncbi.nlm.nih.gov/ pubmed/8291763>. Accessed: Jan. 25, 2018.

RODRIGUES, A.S. et al. Standardization of indirect Elisa and Western Blot for diagnosis of caprine arthritis-encephalitis. Arquivo Brasileiro de Medicina Veterinária e Zootecnia, v.66, n. 2, p.417-424, 2014. Available from: $<$ http://www.scielo.br/scielo.php?pid=S0102$09352014000200014 \&$ script $=$ sci_abstract\&tlng=pt $>$. Accessed: Jan. 25, 2018. doi: 10.1590/1678-41626303.

SALTARELLI, M. et al. Nucleotide sequence and transcriptional analysis of molecular clones of CAEV which generate infectious virus. Virology, v.179, n.1, p.347-364, 1990. Available from: <https:// www.sciencedirect.com/science/article/pii/0042682290903039>. Accessed: Jan. 25, 2018. doi: 10.1016/0042-6822(90)90303-9.

SHAH, C.A. et al. Phylogenetic analysis and reclassification of caprine and ovine lentiviruses based on 104 new isolates: 
evidence for regular sheep-to-goat transmission and worldwide propagation through livestock trade. Virology, v.319, n.1, p.12-26, 2004. Available from: <https:/www.ncbi.nlm.nih.gov/ pubmed/14967484>. Accessed: Jan. 25, 2018. doi: 10.1016/j. virol.2003.09.047

SOUZA, T.S. et al. Interspecies transmission of small ruminant lentiviruses: review and challenges. Acta Veterinaria Brasilica v.6, n.1, p.23-34, 2012. Available from: <https://periodicos.ufersa. edu.br/index.php/acta/article/view/2810>. Accessed: Jan. 24, 2018. doi: 10.21708/avb.2012.6.1.2810

SOUZA, T.S. et al. Duration of passive immunity to small ruminant lentiviruses in lambs. Semina: Ciências Agrárias, v.35, n.2, p.845-856, 2014. Available from: <https://www.alice.cnptia. embrapa.br/bitstream/doc/1000640/1/apDuracao.pdf $>$. Accessed: Jan. 25, 2018. doi: 10.5433/1679-0359.2014v35n2p84.

SOUZA, T.S. et al. Interspecific transmission of small ruminant lentiviruses from goats to sheep. Brazilian Journal of Microbiology, v.46, n. 3, p.867-874, 2015. Available from: <http://www.scielo.br/
scielo.php?script=sci_arttext\&pid=S1517-83822015000300867>. Accessed: Jan. 25, 2018. doi: 10.1590/S1517-838246320140402.

THOMPSON, J.D. et al. Clustal W: improving the sensitivity of progressive multiple sequence alignment through sequence weighting, position specific gap penalties and weight matrix choice. Nucleic Acids Research, v.22, n.22, p.4673-4680, 1994. Available from: <https://www.ncbi.nlm.nih.gov/pubmed/7984417>. Accessed: Jan. 25, 2018.

TORRES, J.A. et al. Produção de antígeno viral para o diagnóstico da artrite-encefalite caprina utilizando um teste imunoenzimático (ELISA). Revista de Ciências Médicas e Biológicas, v.8, n.2, p.107-114, 2009. Available from: <https://portalseer.ufba.br/index.php/cmbio/article/ view/4059>. Accessed: Jan. 25, 2018. doi: 10.9771/cmbio.v8i2.4059.

VILLORIA, M. et al. Detection of small ruminant lentivirus in environmental samples of air and water. Small Ruminant Research, v.110, n.2-3, p.155-160, 2013. Available from: $<$ https:// www.sciencedirect.com/science/article/pii/S0921448812004853>. Accessed: Jan. 25, 2018. doi: 10.1016/j.smallrumres.2012.11.025. 